\title{
Benchmarking and valuation issues in measuring depreciation for European office markets
}

Article

Accepted Version

Crosby, N., Devaney, S. and Law, V. (2011) Benchmarking and valuation issues in measuring depreciation for European office markets. Journal of European Real Estate Research, 4 (1). pp. 7-28. ISSN 1753-9269 doi:

https://doi.org/10.1108/17539261111129443 Available at https://centaur.reading.ac.uk/22718/

It is advisable to refer to the publisher's version if you intend to cite from the work. See Guidance on citing.

To link to this article DOI: http://dx.doi.org/10.1108/17539261111129443

Publisher: Emerald

All outputs in CentAUR are protected by Intellectual Property Rights law, including copyright law. Copyright and IPR is retained by the creators or other copyright holders. Terms and conditions for use of this material are defined in the End User Agreement.

www.reading.ac.uk/centaur 
Central Archive at the University of Reading

Reading's research outputs online 


\title{
Benchmarking and Valuation Issues in Measuring Depreciation for European Office Markets
}

\author{
Neil Crosby ${ }^{\#}$, Steven Devaney* and Vicki Law ${ }^{\#}$ \\ \# School of Real Estate and Planning
University of Reading, Reading, UK \\ * University of Aberdeen Business School \\ Aberdeen, UK
}

Published in 2011 in the Journal of European Real Estate Research,

Vol. 4, Issue 1, Pages 7-28

DOI: http://dx.doi.org/10.1108/17539261111129443

\section{Acknowledgements}

The authors acknowledge the funding for the European Depreciation project provided by the Investment Property Forum research programme, and the individual industry sponsors to that programme. They also acknowledge the input by Malcolm Frodsham and Rebecca Graham of Investment Property Databank for their work in identifying, constructing and analyzing the datasets and the Investment Property Forum steering group for their valuable comments and insights throughout the project. It should, however, be noted that the findings and interpretations of this study are those of the authors and do not necessarily reflect the views of the organisations mentioned. Finally, the authors are grateful to Claudia Murray, Research Officer at the University of Reading, for her input into the spatial and legal aspects of the wider depreciation research programme.

This article is (c) Emerald Group Publishing and permission has been granted for this version to appear here (http://centaur.reading.ac.uk/). Emerald does not grant permission for this article to be further copied / distributed or hosted elsewhere without the express permission from Emerald Group Publishing Limited. 


\title{
Benchmarking and Valuation Issues in Measuring Depreciation for European Office Markets
}

\section{Keywords}

Depreciation; Rental values; Valuation inconsistency; European office markets

\begin{abstract}
Purpose : The paper addresses the practical problems which emerge when attempting to apply longitudinal approaches to the assessment of property depreciation using valuation based data. These problems relate to inconsistent valuation regimes and the difficulties in finding appropriate benchmarks.
\end{abstract}

Design/Methodology/Approach : The paper adopts a case study of seven major office locations around Europe and attempts to determine 10 year rental value depreciation rates based on a longitudinal approach using IPD, CBRE and BNP Paribas datasets.

Findings : The depreciation rates range from a $5 \%$ pa depreciation rate in Frankfurt to a $2 \%$ appreciation rate in Stockholm. The results are discussed in the context of the difficulties in applying this method with inconsistent data.

Research Implications : The paper has methodological implications for measuring property investment depreciation and provides an example of the problems in adopting theoretically sound approaches with inconsistent information.

Practical Implications : Valuations play an important role in performance measurement and cross border investment decision making and therefore knowledge of inconsistency of valuation practice aids decision making and informs any application of valuation based data in the attainment of depreciation rates.

This article is $@$ Emerald Group Publishing and permission has been granted for this version to appear here (http://centaur.reading.ac.uk/). Emerald does not grant permission for this article to be further copied / distributed or hosted elsewhere without the express permission from Emerald Group Publishing Limited. 
There have been a number of studies measuring depreciation in office markets in the UK and, up to the turn of the century, they appeared to produce remarkably consistent results. This is despite the use of different methods, locations, time scales and different treatments of the data.

These studies were examined by Law (2004) who found that this consistency was an illusion as, when she applied the different measurement techniques to a single data set, far from reducing the variation in results, the variation increased. She identified six measurement issues which combined to produce this wide variety of results. She then proceeded to recommend a consistent approach based on a longitudinal method that measures the decline in rental value of a property against a benchmark that ideally represents a new property in the same location.

This method was utilised by Investment Property Forum (IPF) sponsored research which used the Investment Property Databank (IPD) to investigate rental depreciation across all sectors of the UK commercial property market in 2005 (IPF, 2005). Subsequently the IPF sponsored an extension of this project to European markets. The quantity of data and the shorter length of time that data has been collected in many markets by IPD restricted this study to office markets and to five additional centres outside of the UK. In total, seven office markets were examined including two UK locations both in London; the City and the West End. The European locations were Amsterdam, Dublin, Frankfurt, Paris and Stockholm.

This paper reports the results. However, the main aim of the paper is to examine the problems surrounding the production of the results. The longitudinal approach requires a held sample of properties to be compared to a benchmark based on a new property in the same location. While the sample of properties ages through time, the benchmark is assumed to renew itself continually and depreciation is the rate at which the value of the held sample changes relative to the change in the benchmark. Thus, one important part of this method is the choice of a benchmark to compare with the actual performance of the existing property stock. Values need to be identified and the relative rarity of transaction evidence forces analysts into the use of appraisal based values. A second important component of this approach is, therefore, the use of valuations for both the benchmark and the sample properties.

The remainder of this paper is structured as follows. Section 2 discusses literature relevant to this study. This includes definitions of depreciation, approaches to its measurement and the choice of benchmarks by previous empirical studies. This then leads to a discussion of the

This article is @ Emerald Group Publishing and permission has been granted for this version to appear here (http://centaur.reading.ac.uk/). Emerald does not grant permission for this article to be further copied / distributed or hosted elsewhere without the express permission from Emerald Group Publishing Limited. 
valuation issues arising from the measurement of depreciation, concentrating on valuations in Europe as this is the location of the case study. Section 3 sets out the research questions and data used and section 4 discusses the results. The results suggest major questions concerning data consistency and so section 5 explores the character of the data sources in more detail. Section 6 then concludes as to the issues for both valuation and depreciation research that this study has uncovered.

\section{Literature Review}

\section{Definitions and measurement of depreciation}

There is a well developed economic depreciation literature which defines depreciation as a function of value/price in contrast to the accounting concept of consumption of the asset. The economic depreciation literature discusses change in the value of the asset by both age and by time (Hotelling (1925); Taubman and Rasche (1969); Hulton and Wykoff (1976; 1981a; 1981b; 1996); Jorgenson (1996) and Wolverton (1998)). In particular, the work of Hulten and Wykoff (1981b) identifies depreciation as a change in value due to age. Hotelling (1925) and Taubman and Rasche (1969) describe depreciation as a function of time.

The different approaches lead to different methods of measurement, either longitudinal or cross-sectional. Longitudinal studies collect data over time and therefore consist of a set of repeated observations of the same sample. For a cross-sectional study, data are collected at one point in time. Different cross-sections can be compared, but this differs from a longitudinal study in that the datasets for each cross-section are generally not the same sample. Cross-sectional analysis has been used by depreciation studies in order to isolate age as an explanatory variable of value whilst longitudinal analysis measures value change through time.

The advantages and disadvantages of the different approaches have been well rehearsed elsewhere, primarily in the work of Law (2004), but see also Baum (1991) and Hoesli and MacGregor (2000). It is not the purpose of this paper to revisit this discussion. Meanwhile, there have been several empirical studies of property depreciation carried out in the UK, and they have used a variety of techniques based on both cross-sectional and longitudinal approaches. These include CEM (1999), which adopted a longitudinal approach, Salway (1986) and JLW (1987), which took a cross-sectional approach, and Baum (1991; 1997) and Barras and Clark (1996), who adopted both approaches. More recently, in IPF (2005), a longitudinal approach was used to identify 10 and 19 year depreciation rates in the UK for the three main property types and ten segments from the Investment Property Databank Portfolio Analysis System (PAS). Also, Dunse and Jones (2005) identified age-related depreciation

This article is @ Emerald Group Publishing and permission has been granted for this version to appear here (http://centaur.reading.ac.uk). Emerald does not grant permission for this article to be further copied / distributed or hosted elsewhere without the express permission from Emerald Group Publishing Limited. 
rates of industrial/warehouse property across a number of different local markets around Glasgow using asking rents in the years 1995 to 2000. However, until this point, there has been no consistent approach and few of these studies debated measurement methods and choice of benchmarks in depth.

An exception to this was Law (2004) who recommended the longitudinal approach on the grounds that depreciation is a fall in value through time and it is a relative concept compared with a new asset in the same location. She defined depreciation as:

"the rate of decline in rental/capital value of an asset (or group of assets) over time relative to the asset (or group of assets) valued as new with contemporary specification" (Law, 2004).

As the concept is relative, the longitudinal approach requires comparison of the change in value of specific properties with the change in value of a new property with a contemporary specification in the same location. Additionally this benchmark property has to retain its brand new status through time incorporating new technologies. This paper considers the practical issues of applying such a longitudinal approach to measuring depreciation. Specifically, it addresses two main issues implicit in the application of the longitudinal method. The first is the choice of benchmark and the second is the measurement of value of both the benchmark and the specific properties.

\section{The benchmark}

The studies which used a longitudinal approach required a choice of benchmark and the UK studies used a variety of indicators to satisfy this need. Baum (1991) used the top rent in the sample of properties at the beginning of his time period for analysis and compared it to the top rent in the sample of properties in the last year of the analysis to identify the increase in value of prime rents in the period. Later, Barras and Clark (1996) and Baum (1997) used the Investment Property Databank rental value index as a proxy for rent increases in the location studied and compared this to a held sample of properties. In contrast, CEM (1999) adopted data points from the Hillier Parker Prime Rent Index, now the CBRE Rent and Yield Monitor, as benchmarks and this was also selected as a source of benchmarks by IPF (2005).

Meanwhile, the only studies of depreciation rates in European property markets are those of Turner (2001) and Baum and Turner (2004). These were cross-sectional and in each case used the youngest age group in the sample as the benchmark for the top rent.

This article is @ Emerald Group Publishing and permission has been granted for this version to appear here (http://centaur.reading.ac.uk/). Emerald does not grant permission for this article to be further copied / distributed or hosted elsewhere without the express permission from Emerald Group Publishing Limited. 
The criteria for a benchmark within the context of longitudinal depreciation studies has been examined by Law (2004) and Hoesli and MacGregor (2000). Law suggested that the choice of benchmark was anchored in the definition; thus, depreciation would ideally be measured as the fall off in value from a new building of the same type, but with contemporary specification, in the same location. Hoesli and MacGregor agree. However, in the probable absence of data matching this ideal, Law went on to suggest that a benchmark should be selected with reference to three key characteristics;

- First, the specification should be as new to an appropriate modern design. This is preferred to matching the specification of the existing property, as it ensures that the effect of obsolescence is captured by the measurement.

- Second, in the absence of site specific data, the benchmark should have sufficient coverage and disaggregation so that the location of the property can be matched to the benchmark in as much detail as possible.

- Third, the benchmark itself should not contain depreciation. In a longitudinal setting, this rules out the use of benchmarks derived from the sample itself and it also rules out the use of 'market' benchmarks.

Market benchmarks of rental or capital values are normally based on chain linked growth rates computed from held samples of properties over the measurement interval. Therefore, they include depreciation as they comprise a sample which ages over the measurement interval, regardless of the shortness of that period. Changes in portfolio make-up are only incorporated at the end of the period and reflected from that point forward. This invalidates the choice of Baum (1997) and Barras and Clark (1996) since the IPD rental value index was constructed in this manner and although the IPD dataset has tended to have a relatively constant age profile through time (IPF, 2005), the calculation of rental growth is based on a held sample.'

In contrast, prime indices constructed on a hypothetical rather than 'top rent' basis do not include depreciation as they are constructed based on the rental value or yield of a hypothetical new property - usually in the $100 \%$ pitch of the chosen location. Further, the use of a continually prime index allows the resultant depreciation rate to account for obsolescence. However, the use of a prime index when a sample is comprised of properties in non-prime locations may misstate depreciation as there may be relative differences in performance between prime and non-prime locations through different market conditions. For example, in

\footnotetext{
${ }^{\mathrm{i}}$ More recently, the IPD UK indices have been constructed on a monthly chain-linked basis (even for lower publication frequencies). This reduces, but does not eliminate, this issue.

This article is (c) Emerald Group Publishing and permission has been granted for this version to appear here (http://centaur.reading.ac.uk/). Emerald does not grant permission for this article to be further copied / distributed or hosted elsewhere without the express permission from Emerald Group Publishing Limited.
} 
times of high occupier demand, the differential between prime and non-prime buildings may reduce.

In the UK, the CBRE Rent and Yield Monitor (CBRE, quarterly) provides a set of long term data based on an assessment of the prime rental value and yield in a large number of locations. The hypothetical new properties are revalued quarterly and the assumed specifications are updated with technological change. The coverage is wide but they do assume the $100 \%$ pitch in each of the micro-locations measured. The sample currently consists of around 300 shop locations, 215 office locations, 115 industrial and 60 retail warehouse locations across the UK (CBRE, 2007). The dataset is valuation rather than transaction based.

The use of valuations

Both benchmark and sample data in previous depreciation studies has been based on valuation data. Sale and rental transactions in commercial property are infrequent and, as a result, valuation based indices have been developed to measure property performance. There is a well defined literature addressing the limitations of valuations in identifying accurately the exchange price of property and this literature includes issues such as accuracy, smoothing and lagging (see, for example, Geltner et al. (2003) and Brown and Matysiak (2000)). This literature suggests that valuers cannot precisely identify the probable sale price, will vary between themselves in valuing the same property, will be biased towards undervaluation in most cases and will understate the volatility of changes in value, thus smoothing the peaks and troughs of the market. Furthermore, there is another branch of literature which suggests that valuations can be influenced by clients or other interested parties that have access to the valuer during their appointment and/or the valuation production process (see the reviews by Diaz (1999; 2002) and Crosby, et al (2010)).

These two strands to the valuation literature have implications for the comparison of two sets of valuations. Smoothing, accuracy and lagging could cause inconsistencies between the two datasets in the short term, but their influence should be less over longer periods. Meanwhile, client influence could be applied to the sample properties but not the benchmark (assuming the benchmark was chosen from the hypothetical indices indicated previously). However, again over the long term, the valuations would have to be influenced significantly and systematically for this to have a major impact. Given the imprecise nature of de-smoothing and the lack of data on the extent of client influence, any attempt to transform valuation data to improve analysis of shorter term depreciation rates would be too subjective.

This article is @ Emerald Group Publishing and permission has been granted for this version to appear here (http://centaur.reading.ac.uk/). Emerald does not grant permission for this article to be further copied / distributed or hosted elsewhere without the express permission from Emerald Group Publishing Limited. 
There is also a literature on the application of valuation in different countries that has been initiated by the globalization of investment markets and the search for consistency of information across international markets. The Jones Lang LaSalle Transparency Index includes valuations in its assessment of which countries are the most transparent for global investors (JLL, 2010). Transparent and consistent valuation regimes are particularly important for the development of global indices of performance, such as the IPD Global Index.

The IPD Index Guide (IPD, 2008) defines both capital value and rental value for use in their (global) performance measurement indices. Capital Value is defined as

"(open)" market capital values as supplied by the portfolio's valuers. In the UK these must be in accordance with the RICS definition of (Open) Market Value, stated net of purchasers' costs. In other markets locally defined standards are reviewed and where appropriate adopted, subject to the overriding requirement that any prescribed method is based upon open market principles".

Market rental value is defined as:

"the rent that the valuer estimates could be charged if the unit were let in the open market on the valuation date".

The intention is clear. IPD want to use valuations in their performance measures which adhere to the general concept of value in exchange and that adopt the market value definition in the UK and similar definitions in other countries. All IPD (2008) suggest is that local standards are acceptable for its performance measurement role.

Valuers in the different case study countries do adopt different valuation standards. According to McParland et al (2002), Sweden is heavily dominated by the local (national) standard and the Netherlands and Germany by both the local standard and RICS standards, which are split into two sections; global practice standards and guidance and UK practice standards and guidance. In France a combination is used comprising international, regional, national and RICS standards. The UK is dominated by the national (RICS) standard (Red Book) which is mandatory for UK valuations undertaken by Chartered Surveyors and Ireland also uses the UK Red Book.

Adair et al. (1996) has information on valuation bases adopted within 12 countries within Europe. The valuation of investment properties for insurance companies, unit trusts and other

This article is $@$ Emerald Group Publishing and permission has been granted for this version to appear here (http://centaur.reading.ac.uk/). Emerald does not grant permission for this article to be further copied / distributed or hosted elsewhere without the express permission from Emerald Group Publishing Limited. 
investors are based on market valuation concepts. The only possible exception is Germany where Downie et al. (1996) suggest that the German definition of market value may include elements of average or "normalising" price rather than best price estimation. There is, however, little work on differences of interpretation in different countries.

McParland et al. (2002) also identified differences in the education of valuers and valuation methods adopted within Sweden, Germany, The Netherlands and France. They suggested that information transparency is a key factor in which technique is adopted and that cash flow methods are generally far more popular in Sweden and The Netherlands than they are in Germany and France. They also suggested that German valuers have a training and education programme more based in the built environment discipline than some of the other countries. This is also suggested by Bruhl (2001). In the UK, valuations are well documented and market valuations are mainly comparison based (see, for example, Baum and Crosby, 2007)

One area of inconsistency very pertinent to this research is the interpretation of rental value and this is currently under discussion between the RICS and IPD in the UK. Crosby and Murdoch (2001) investigated the interpretation of rental value adopted by UK valuers providing data to IPD. They found a number of variations based around effective and headline rental values, and provable and achievable rents. Different data providers were applying different assumptions concerning actual or notional lease terms as well as stripping out inducements in some cases and not in others. Other interpretational issues include anecdotal comment that in some countries an average rent is used, not a best rent. Added to this is the possibility that, given the greater use of indexation and other non-market based rent revision provisions, mainland European investors may not be as concerned with market rental value estimates as in the UK.

Furthermore, in addition to the headline/effective rent issue, there is anecdotal evidence that Germany is different in another respect. The IPD guide to the German index indicates that the definition of rental value is not a value in exchange concept; rather it is a sustainable value concept (IPD GmbH, 2007). Within the guide, the English translation of the German title of the rental value section is "Market Rental Value/ERV" and the translation of the text is:

"The expected sustainable income from the property as delivered by the valuation expert, but excluding operating costs."

\footnotetext{
ii The word "open" is a throwback to when the UK market value definition was called open market value - this is no longer the international or UK definition.

This article is @ Emerald Group Publishing and permission has been granted for this version to appear here (http://centaur.reading.ac.uk/). Emerald does not grant permission for this article to be further copied / distributed or hosted elsewhere without the express permission from Emerald Group Publishing Limited.
} 
This discussion suggests that there may be some unanswered questions concerning the basis of valuation adopted for rental value applied to properties included in IPD in different countries - there may be differences in (a) the bases, (b) the interpretation of bases and (c) the importance placed on rental valuations in different countries, in particular, the six countries represented in this depreciation study. These interpretations may not be consistent within countries and the interpretation of rental value for the valuation of the benchmark may not be mirrored in the valuation of the IPD sample.

There is one other issue to be considered. In the current downturn, the smoothing and lagging debate in valuation has been carried on in European practice by reference to the speed (or otherwise) at which the capital value component of the IPD indices have fallen. It is possible that the approach to benchmark valuation may be less inhibited than that for valuations of properties within portfolios and so there may be some mismatch between the benchmark and the sample in specific years that may, in turn, impact on the calculation of depreciation rates. The IPD Global Index (IPD, 2009) indicates that capital value falls in 2008 in Ireland and the UK were far higher than in Sweden and France, which in turn were higher than the Netherlands and Germany. Although there are obvious economic reasons why differential falls in value occur, there is some discussion concerning the speed at which valuations mark to market (IPF, 2009) and whether the indices of individual countries exhibit differential smoothing. Anecdotal comment would suggest that Germany is not the only country in this study where rental valuations may be excessively smoothed from market prices.

\section{Research Questions and Data}

The original aim of this research was to determine rental value depreciation rates for a number of European office markets. As noted earlier, the longitudinal approach is one of two accepted methods of attempting to identify depreciation rates for investment property. However, concerns regarding the choice of benchmarks and the consistency of valuations across Europe indicate why the study refocused its objectives onto the application of the approach rather than the results of the case study themselves.

The research question concerning benchmarks is whether the availability of benchmarks in any market being examined fits the criteria of matching a new property to the same location as the sample property - is there sufficient availability of data to undertake the matching?

The research questions concerning valuations centre on whether the approach to the valuation of the benchmarks differs from the approach to the valuation of the sample properties. The review suggests a number of reasons why this may be so. First, different approaches to the valuation of benchmarks and sample properties could be caused by the fact that one valuation

This article is $@$ Emerald Group Publishing and permission has been granted for this version to appear here (http://centaur.reading.ac.uk/). Emerald does not grant permission for this article to be further copied / distributed or hosted elsewhere without the express permission from Emerald Group Publishing Limited. 
is for a hypothetical index and one is of an actual property and could be for a number of purposes such as performance measurement or use within financial statements. For example, client influence may be applied to one set of valuations but not the other. There could be more basic valuation differences by valuers adopting different bases or interpretations such as a different reporting of effective or headline, achievable or provable rents.

Second, there are country specific issues such as different interpretations of basic valuation definitions and methods between countries and by different valuers within countries - for example, sustainable rental value valuations in Germany. For these reasons, the behaviour of benchmark rental value assessments against the sample rental value assessments needs to be examined.

The case study locations were Amsterdam, Dublin, Frankfurt, Paris and Stockholm, along with the UK office markets of the City and the West End of London. The choice of these locations was dictated by data availability within the main data provider, Investment Property Databank. It was considered that a 10 year period was the minimum time span over which depreciation could meaningfully be measured and, as a result, only those countries with performance measurement databases stretching back to 1997 or earlier were included, with the measurement of depreciation undertaken from end-1997 to end-2007.iii

An analysis of the state of the individual economies and property markets by reference to city level data on GDP growth, employment, rental value growth and vacancy rates suggests that three different stages in the cycle can be identified - an improving market in the period 1997 to around 2000, a weakening market in the period 2000 to 2003 and an improving market from 2003 to 2006 (IPF, 2010, using data from Experian and CBRE). There are slight differences in the individual locations concerning turning points, but the ten year period does appear to cover periods of both relative strength and weakness in the economies and occupier markets of the cities in question.

A longitudinal design requires data on individual assets held throughout the period under study. The longer the period being analysed, the smaller the potential sample will become because of demolition, redevelopment, major refurbishment or sale out of the data set. This trade off between length of the study and declining data sets meant that only those office markets of sufficient size within the IPD databanks could be considered. However, these markets are also likely to be the ones of most interest to international property investors.

\footnotetext{
${ }^{i i i}$ As it happens, depreciation for Paris could only be measured over 8 years (1999-2007) owing to a lack of market rental value data in the IPD France databank.
}

This article is (c) Emerald Group Publishing and permission has been granted for this version to appear here (http://centaur.reading.ac.uk/). Emerald does not grant permission for this article to be further copied / distributed or hosted elsewhere without the express permission from Emerald Group Publishing Limited. 
Only properties within IPD in each location that had a market rental value and floorspace figure recorded at both the start and end of the period, as well as building expenditure and capital value data over the whole period, were included in the sample datasets. In most cases, the selected assets also had a complete set of intermediate rental values available, but a notable exception to this was Paris. Here, the sample used to measure the 8 year depreciation rate is larger than that used in the year-by-year analysis of rental values reported later. A number of exclusions from the datasets were then made; for example, if assets were subject to major refurbishment or redevelopment or if an appropriate benchmark for new property rental values could not be found for their location. The resulting sample sizes for each market are displayed in Table 1.

\section{Insert Table 1 here}

The approach also requires benchmarks in each location. Of the available series in the UK, IPF (2005) concluded that the CBRE Rent and Yield Monitor, discussed earlier, provided the most appropriate set of benchmarks in the absence of the model benchmarks noted above. This source was also used in this study and the same kinds of benchmarks were sought for the other European markets. In the event, CBRE and BNP Paribas Real Estate kindly provided disaggregated rent point data for locations within each of the chosen cities and these rent points were matched with the properties in the datasets used for the project.

The total number of rent points that were available for each city across the analysis period from either CBRE or BNP Paribas Real Estate is shown in Table 2. In the event, not all locations covered by the benchmarks were represented in the sample of assets for each city this explains the difference between the number of rent points available and the number that were used. At the same time, a small number of buildings in each market could not satisfactorily be matched owing to a lack of rent points in their locality. The numbers involved were not significant apart from the case of Stockholm, where there was a shortage of rental benchmarks that stretched back for the whole measurement period.

Insert Table 2 here

Finally, it is important to consider the nature of the held samples and whether they are representative of their markets. Comparisons based on the mean age, capital value and floorspace of the sample relative to all IPD data for each city suggest that the samples are representative and that conclusions from analysis of each sample can be applied more generally. Meanwhile, a separate test of survivor bias in terms of performance (whether the held sample outperforms properties that were traded in and out of the IPD databank) does not show any consistent pattern of this nature. More details of these tests are given in IPF (2010).

This article is $@$ Emerald Group Publishing and permission has been granted for this version to appear here (http://centaur.reading.ac.uk/). Emerald does not grant permission for this article to be further copied / distributed or hosted elsewhere without the express permission from Emerald Group Publishing Limited. 
However, a comparison of the rental value per square metre of the benchmarks compared to that for the sample assets produces two anomalies. The first is that the rental value per square metre (psm) of the sample (older properties) is higher than that of the benchmark (new properties) in Frankfurt at the beginning of the analysis period in 1997. The second is that the rental value psm of the sample in the City of London is only around $40 \%$ of the level of the benchmark. This raises questions about rental value estimates which are examined later in this paper.

\section{Depreciation rates in Seven Major European Office Markets}

Table 3 provides the depreciation rates together with the rental growth recorded by the samples and set of benchmarks in each case. It also indicates the amount of irrecoverable expenditure by investors on maintenance or physical improvements expressed as an annualised average of capital value. ${ }^{\text {iv }}$ Although not relevant to the issues being discussed in the paper, rental depreciation rates cannot be divorced from expenditure by owners designed to counter the effects of depreciation (IPF, 2005).

Overall, the rental depreciation rates found by this research are very mixed for the cities, with some samples showing appreciation against benchmarks over the time scale of the study. There does not seem to be a consistent relationship between rental growth and depreciation. Although the highest rental value growth (for both samples and benchmarks) is in London West End and Dublin, which also have high depreciation rates, Frankfurt has the second lowest rental growth in the benchmark, but the highest depreciation rate. Meanwhile, the City of London, with the lowest benchmark growth does not show appreciation, unlike Paris and Stockholm who have high rental growth rates in the sample and do show appreciation. ${ }^{v}$

Insert Table 3 here

There are issues related to the individual locations which may impact on the results. For instance, in Stockholm, there is only one benchmark and although all the properties are in the same central city area as the benchmark, each location would have had to have retained its value relative to the benchmark over the ten year period. The high appreciation rate suggests

\footnotetext{
${ }^{i v}$ In the UK and Ireland, maintenance costs have not always been collected separately from other, regular costs such as property management fees. Thus, for London and Dublin, the measurement of maintenance expenditure is performed using a more aggregated data field, which means that the total expenditure rate will be a slight over-estimate.
}

This article is (c) Emerald Group Publishing and permission has been granted for this version to appear here (http://centaur.reading.ac.uk/). Emerald does not grant permission for this article to be further copied / distributed or hosted elsewhere without the express permission from Emerald Group Publishing Limited. 
that the individual locations have improved relative to the benchmark, i.e. the office market has expanded spatially and more peripheral locations may have improved relative to the previous prime location. Without more investigation of the development of Stockholm CBD throughout the analysis period, the appreciation rate should be treated with caution.

The longer leases of the UK and Dublin may lead to different patterns in the timing of capital expenditure. In particular, if expenditure is less frequent as a result, this could have consequences for the depreciation that these properties experience (Baum and Turner, 2004; Baum and Devaney, 2008). Meanwhile, the high levels of new development relative to existing stock in Frankfurt, Amsterdam and Dublin have impacted on vacancy rates and may influence the rates of depreciation in different market states. Yet, as indicated previously, the economic indicators suggest that there is some consistency in the changes in the economies and property markets of the different cities with a weaker period in the early 2000s that caused rental value decline in all locations in 2002 and 2003 (Figure 1).

\section{Insert Fig 1 here}

For most of the properties in each sample, not only were the initial and final rental values for the period known, but also all the intervening year end rental values. This enabled the calculation of annual rental growth and depreciation rates. Figure 2 graphs the annual rental depreciation rates and, as expected, there is considerable variation year on year. However, it appears that there are some changes through time with higher depreciation rates (lower appreciation rates) at the beginning and end of the period than in the middle. Figure 3 sums the depreciation rates of each market in each year to reveal a distinct pattern.

Insert Fig 2 here

Insert Fig 3 here

Two hypotheses might be proposed for how the values of new and aging properties, and thus depreciation rates, might be expected to behave over the course of a market cycle. Focusing on weak markets, it could be argued that new and/or prime properties (proxied by the benchmark) are more likely to let than older, secondary properties (proxied by the sample, which contains a mix of assets) and that newer property values will remain healthier than the older, more secondary property. In this scenario, depreciation rates would rise during weaker market conditions.

\footnotetext{
${ }^{\mathrm{v}}$ Disaggregated measurement by sub-market within each city and by age bands was attempted, but did not shed light on discrepancies between cities or the dynamics of depreciation within them and so they are not reported in this paper, but see IPF (2010).

This article is @ Emerald Group Publishing and permission has been granted for this version to appear here (http://centaur.reading.ac.uk/). Emerald does not grant permission for this article to be further copied / distributed or hosted elsewhere without the express permission from Emerald Group Publishing Limited.
} 
Alternatively, it could be suggested that new properties will suffer more than existing assets in weaker markets. At first sight, this seems a less comfortable line of argument, but could be justified if, during a downturn, occupiers were more inclined to find cheaper space and would not rent new space unless at a big discount to its usual cost. However, these discounts would normally be in the form of incentives and these might not be incorporated into rent reductions if headline rents are used for benchmark and sample valuations. Another issue which could impact on the short term shape of depreciation rates is the different supply and demand characteristics in the same market at the same time for prime and secondary property. Regardless of market state, a misalignment of supply of one quality of stock against another could increase or decrease depreciation rates over the short term.

The patterns shown in Figures 2 and 3 marry with market state indicators and suggest that the better the state of markets, the more depreciation is encountered and visa-versa; that in weak markets, there is less depreciation (more appreciation). Thus, existing properties appear to have lost out to newer properties in the stronger lettings market and experience less rental growth than the benchmark as a result. Conversely, in the weaker lettings market, growth in the existing assets did not fall away as much. It may appear, therefore, that this supports the second hypothesis put forward above.

However, these conclusions are counter-intuitive and there may be another reason for them that needs examination. It is based on the methodology adopted and its use of rental value estimates. This is best explored by comparing through time the benchmark rental value change and the rental value change of the sample properties in each location. These two constituent parts of the depreciation equation are illustrated below for each of the seven locations in Figures 4 to 10.

Insert Fig 4 here

In London West End, benchmark and sample rental values are very closely matched showing similar shapes in terms of falling and rising at the same time periods and similar levels of volatility. The depreciation rate is therefore relatively consistent mainly ranging between $+/-5 \%$ pa. Depreciation is lower in the weaker lettings market period.

Insert Fig 5 here

London City also shows some consistency between movements in the rental values of the benchmark and the sample, with similar volatility. The benchmark and sample rental growth rates vary most in the years 2001 and 2006 but all of the other years are relatively close. The

This article is (๑) Emerald Group Publishing and permission has been granted for this version to appear here (http://centaur.reading.ac.uk/). Emerald does not grant permission for this article to be further copied / distributed or hosted elsewhere without the express permission from Emerald Group Publishing Limited. 
benchmark growth rate accelerates in 2006 but moves back sharply in 2007 . This may be the identification of the start of a downturn identified in the benchmark but not by the sample, indicating some lagging, or it could be that 2006 was relatively too high. The depreciation pattern is less clear with two depreciation peaks in 2001 and to 2006.

Insert Fig 6 here

Annual change in the Dublin benchmark and the sample rental values has a consistent pattern with both falling sharply in 2001 and rising more gently in the later years of the period to 2006. However, the changes in the benchmark are more volatile than changes in the sample rental values and the sample also appears to lag the benchmark with turning points in 2000 and 2003 in the benchmark followed by similar turning points of 2001 and 2004/2005 in the sample. In 2005 and 2006 the benchmark grows significantly more than the sample but the sharp falling off of growth rate in 2007 is not mirrored in the sample. The sample appears to be lagged and smoothed relative to the benchmark. Depreciation rates are therefore low (appreciation) where the lag in the turning point is most marked (2000 and 2007) or where the benchmark growth is falling at a higher rate than the sample (for example, 2002). It is highest when the benchmark growth is accelerating at a greater rate than the sample in 1999 and between 2003 and 2006.

Insert Fig 7 here

In Amsterdam, the benchmark and sample rental values show some similar characteristics to Dublin. The benchmark changes are more marked than the sample rental value changes and fall faster in the period 2000 to 2003 and rise more sharply in 2004 to 2006 . The sample rental value changes lag one of these turning points as the rental growth in the sample doesn't start to accelerate until 2006, two years after the benchmark. However, both growth rates peak in 2000 and fall in 2001. As in Dublin, the benchmark growth rate reduces significantly in 2007 but the sample rental growth rate continues to rise. The pattern of depreciation follows the pattern observed elsewhere with the lowest depreciation (highest appreciation) generally occurring in the period when the growth rates are decelerating (2001 to 2003) and the highest when they are accelerating (2004 to 2006). This ignores some slightly odd observations for the benchmark and sample rental growth rates at the beginning of the period.

Insert Fig 8 here

Although the Paris data is for two years less than the other locations, a similar pattern of rental growth rates can be observed. Both benchmark and sample rental value growth is decelerating between 1999 and 2002 before recovering to 2007. There is no hint of the 2007

This article is $@$ Emerald Group Publishing and permission has been granted for this version to appear here (http://centaur.reading.ac.uk/). Emerald does not grant permission for this article to be further copied / distributed or hosted elsewhere without the express permission from Emerald Group Publishing Limited. 
downturn indicated in the benchmarks for Dublin, Amsterdam and the City of London. The benchmark and the sample behave very similarly in the period 2002 to 2007 but there are much wider variations in 2000 and 2001 caused by a huge spike in the benchmark growth rate in 2000.

Insert Fig 9 here

The benchmark and sample rental value growth rates are very consistent in Stockholm with both the benchmark and the sample growth rates peaking in 2000, falling in 2001 and recovering gently in 2002 onwards. As in London West End and Paris, there is no sign of a downturn in 2007. The benchmark is more volatile than the sample in 2000 and 2001, growing more in 2000 and falling more in 2001, which does appear to cause a bit of lagging in the sample rental value growth in 2002. The greater fall in the benchmark compared to the sample in 2001 produces a large element of appreciation in the sample relative to the benchmark and this is largely responsible for the appreciation rate over the whole period.

Insert Fig 10 here

Finally, Frankfurt exhibits a completely different pattern to the other locations caused by a significant variation between the benchmark rental value change and the sample rental valuation change. The benchmark indicates a downturn in 2001 and 2002 and a recovery in 2003 onwards. The sample rental values are virtually flat with a slight downward slope from 2001 onwards. The sample records small falls in rental value every year in this period with the benchmark indicating large falls in rental value in 2002 and 2003 and increases in 2005 and 2007. The levels of depreciation are dominated by the mismatch between these two indicators of rental value change with huge appreciation rates when the benchmark is growing less (higher rates of rental decline) than the sample and huge depreciation rates when growth rates are higher than in the sample.

Further analysis of the valuation and benchmark issues are set out in Table 4. This analysis compares the rental performance of the whole cohort with the benchmark and with the newest set of properties within the sample cohort. This is to reinforce that it is not simply age effects within the sample that are driving any differences in rental growth patterns over the period. The correlations between the benchmark and young sample (Column 2), benchmark and whole sample (Column 3) and young sample and whole sample (Column 4) are all high expect for Frankfurt.

Insert Table 4 here

This article is $@$ Emerald Group Publishing and permission has been granted for this version to appear here (http://centaur.reading.ac.uk/). Emerald does not grant permission for this article to be further copied / distributed or hosted elsewhere without the express permission from Emerald Group Publishing Limited. 
In summary, London was the city that has the least valuation inconsistency. But both Dublin and Amsterdam have some element of lagging over this period, with sample rental values moving after the benchmark. Movements in sample and benchmark in Paris since 2000 seem to be consistent as are movements between the two data sources in Stockholm. However, Frankfurt starts the study period with the sample rental value above that of the benchmark and then the sample appears to have virtually no movement whilst the benchmark shows significantly more volatility. Table 4 shows that there is no correlation between the benchmark and sample valuation series in the Frankfurt office market (Column 2).

\section{Discussion of issues raised by the results}

The headline rental depreciation rates derived from this study show very little consistency and so conclusions are difficult to construct. In three of the locations (Stockholm, Paris and Amsterdam), the sample properties have grown more than the benchmark, creating appreciation rather than depreciation rates. This begs a number of questions about how markets behave but also raises technical questions concerning the data used.

The basic analysis of rental depreciation rates ranges from nearly $5 \%$ pa depreciation in Frankfurt to appreciation rates of almost 2\% pa in Stockholm over a 10 year period to 2007. The time period of the analysis spans a minor market cycle with a weakening of both economic and property market indicators in the early 2000s. The year-by-year rental value change and depreciation rates were computed to explore the potential influence that this cycle might have. They show that rental value depreciation seems to increase in stronger lettings markets and decrease in weaker lettings markets. Thus, existing properties seem to lose out to newer properties in the stronger lettings market. However, when markets are weaker, existing properties do relatively better than new by not depreciating as much.

These conclusions are tempered by data issues concerning valuations that could explain the variability in the results. Given the analysis of the German valuation system and approach, it is safe to conclude that rental valuations done for the individual assets and those undertaken for the benchmark are based on a different approach, and trying to discern trends from analysis of this data is fraught with difficulties. Frankfurt's results are not the only ones which are affected by valuation issues but they appear to be particularly affected by major differences between the shape of the benchmark valuations and the sample valuations. The use of sustainable rental values is proven here beyond doubt and this would suggest that any analysis of markets using rental value performance data from actual properties valued using the German approach is bound to show differences between Germany and other European markets.

This article is $@$ Emerald Group Publishing and permission has been granted for this version to appear here (http://centaur.reading.ac.uk/). Emerald does not grant permission for this article to be further copied / distributed or hosted elsewhere without the express permission from Emerald Group Publishing Limited. 
Over the longer term, average depreciation rates may be more consistent, but, in the case of Frankfurt, the fact that the average sample value is higher than the benchmark value at the start of the period is evidence of a major issue of inconsistency. Is it feasible that the average rental value of 17 properties of varying ages is higher than the average rental value of a hypothetical set of new properties in the same locations as the sample properties? If not, then the different approach to the valuations of the sample and the benchmarks is a major question.

It may be too simplistic to suggest that only Frankfurt has a major valuation problem to address. It is apparent that all of the benchmarks appear to be more volatile than the sample series. The sample properties seem to recover relative to benchmarks when rental growth slows. This may be a valuation process issue with a different mentality of valuers towards benchmark assessments than they have towards actual valuations within a portfolio. Where they are more conservative, it introduces more lagging and smoothing in the sample than in the benchmark. There is also the issue of whether both sample and benchmark valuations are using the same type of rental values; provable or achievable, and effective or headline. We have not investigated whether there are any client influence issues, but if there are any pressures they would be on the sample valuations only.

The valuation issue raises some serious questions for the similar study of the UK market (IPF, 2005). If the methodology has not worked well in Europe, why shouldn't the UK results be contaminated in the same way? However, it does appear that in London the valuation issue is not a major influence on the results. In London West End, the performance of both benchmark and sample valuations are consistent, whilst in Stockholm and London City there also appears to be very similar turning points in the two types of series (apart from the last year in London City). Given this, the UK results in IPF (2005) would appear to be robust. In the UK study, the benchmark valuations were provided by a single supplier and that same supplier is now the largest valuation firm supplying portfolio valuations in the UK. The greater consistency between the benchmark and sample valuations is therefore not surprising.

However, there are greater concerns in Dublin, Paris and Amsterdam where this consistency of supply does not exist and there does appear to be some lagging in the sample valuations compared to the benchmark. We have not investigated the possible impact of lagging on depreciation rate measurement but feel that it deserves more attention in the future.

On account of the valuation issues that have been outlined in this report, we feel that any conclusions on the performance of prime and secondary properties through different market states are not reliable and remain as questions unanswered by this study. However, in the UK market, where the valuation issue appears to be of less concern, the pattern of depreciation

This article is @ Emerald Group Publishing and permission has been granted for this version to appear here (http://centaur.reading.ac.uk/). Emerald does not grant permission for this article to be further copied / distributed or hosted elsewhere without the express permission from Emerald Group Publishing Limited. 
through the cycle was the same as that identified elsewhere, with the benchmarks growing at a faster rate than the sample in the higher growth periods but falling by more than the sample when rental growth was less. This is true for both the whole sample and the newest properties within the sample, so, even here, the year on year results appear to be a product of valuation differences rather than a prime-secondary property difference.

In the case of Paris, which also indicated appreciation, there are a number of benchmark rent points. But the benchmarks are compiled by leasing agents who give an idea of the range of rents in an area, and the research used the top of this range on the grounds that this should be closest to the 'new' rent. Therefore, the benchmark data is further from the required definition for this project than in some other markets. Meanwhile, rental values in IPD are undertaken by valuers and, traditionally, agents and valuers have been kept apart in this market; hence, organisation of the valuation profession in France may be another issue, contributing to the difference between benchmark and property measures.

One other data question is raised by the City of London. In both the IPF (2005) UK depreciation study and in this study, City of London offices appear to have little depreciation and this has always been difficult to fully understand. The City stands out in particular in one of our analyses - the comparison of the average rental value of the sample against the average rental value of the set of matched benchmarks. The sample appears to have a rental value of only $35 \%$ to $40 \%$ of that of the benchmark, despite the fact that the average age of the sample here is only 22 years old at the start of the analysis period. This gap between the value of the sample and the benchmark may be having an impact on the results but this has not been investigated in this research.

\section{Conclusion}

The original aim of this research was to produce rental depreciation rates for a number of office markets in Europe and to analyse the impact of asset expenditure on these rates. Such rates were computed, but they are so fraught with difficulties that we do not feel they give a good indication of the levels of depreciation in Europe. The major issue that arises is with the method of measuring depreciation. To be more precise it is with the application of the method, which requires the relative differences between rental value movements in a held sample and an appropriate new benchmark property to be assessed. This approach appeared to work well in the UK but its application to Europe has not been easy. This has resulted in difficulties in the interpretation of the depreciation results on a country by country basis (with the exception of the UK) due to the inconsistent nature of the valuation based indices and the relationship between these indices and the available benchmarks. Further, the existence of a measure on a country or international city basis encourages cross border

This article is $@$ Emerald Group Publishing and permission has been granted for this version to appear here (http://centaur.reading.ac.uk/). Emerald does not grant permission for this article to be further copied / distributed or hosted elsewhere without the express permission from Emerald Group Publishing Limited. 
comparison which holds further interpretational difficulty as the inconsistencies apparent within countries also differ between countries.

Two issues were apparent. The first was the quality of each benchmark in terms of the number of rent points in each location and the matching of those rent points to the sample. In Stockholm, one rent point covered the city centre and so differences between micro-locations within the city centre could cause depreciating properties to appreciate against the benchmark if the benchmark location is deteriorating against the sample as a whole.

Second, in attempting to apply the method, differences in the interpretation of valuations may be causing major distortions to the results. This paper provides some evidence for the valuation debate in Germany and empirical evidence of the application of sustainable rents. However, the literature review raised a number of other possibilities for why valuations may differ and this research has not been able to address them directly. Client influence could be present and be a cause for some of the observations of differences between the performance of sample and benchmark valuations. The use of different rental values could also play a part: for example, achievable versus provable and headline versus effective rents. These issues are part of a wider valuation agenda and are not confined to depreciation.

Inconsistencies in either valuation bases or interpretations of those bases leading to variable application are a performance measurement industry nightmare as the main global property performance measures are valuation based. The use of global indices and information to support global investment analysis and investment is predicated on a consistent basis and so major anomalies between countries are at best misleading and could lead to unsound crossborder investment decisions. It is the conclusion of this paper that a major research question for the industry is the reconciliation of global valuation practices and interpretations.

Valuation regulators under the umbrella of the International Valuation Standards Committee have come a long way in obtaining global agreements on definitions for different concepts of value including market value. However, consistent definitions and standards are only a first steps towards consistency of practice and it is clear that there are major inconsistencies both within and between countries. A more consistent global regime would have more controls over client influence, such as a procedure whereby draft valuation meeting minutes have to be taken and can be monitored (as introduced by RICS in the UK). It would also have a consistent approach to the provision of rental value and consistent interpretations of bases across borders, clearly not the case at present. There needs to be an international response and that should be orchestrated by the major performance measurement providers and the IVSC with the first step being a more detailed investigation of how valuers actually operate.

This article is $@$ Emerald Group Publishing and permission has been granted for this version to appear here (http://centaur.reading.ac.uk/). Emerald does not grant permission for this article to be further copied / distributed or hosted elsewhere without the express permission from Emerald Group Publishing Limited. 
Benchmarks need to be assessed in a similar way and although they are not likely to be affected by client influence, they are affected by the different definitions and interpretations of rental value. For some countries such as Sweden, the only solution is for more rent points within centres - until that happens the matching process cannot effectively be undertaken.

As far as depreciation is concerned, if the current datasets and valuation regimes in mainland Europe are not robust enough to identify depreciation via a longitudinal method, the alternative is to construct a cross-sectional study. The advantages are that inconsistencies between sample and benchmark valuations do not occur and the data is not confined to properties that have been in the dataset over the long-term. Some disadvantages have been discussed in this paper, such as the reliance on age as the main factor in determining cohorts and the single time point at which the analysis is performed. However, it would seem that, given the methodological problems identified in this study, cross sectional analysis is the alternative approach in the short-term until data quantity and quality improves, despite all of the theoretical limitations in matching the cross sectional method to the robust definition of depreciation.

This article is $@$ Emerald Group Publishing and permission has been granted for this version to appear here (http://centaur.reading.ac.uk/). Emerald does not grant permission for this article to be further copied / distributed or hosted elsewhere without the express permission from Emerald Group Publishing Limited. 


\section{References}

Adair, A., Downie, M. L., McGreal, S. and Vos, G. (Eds) (1996), European Valuation Practice. E \& FN Spon: London.

Barras, R. and Clark, P. (1996), "Obsolescence and Performance in the Central London Office Market", Journal of Property Valuation and Investment, Vol 14 No. 4 pp. 63-78.

Baum, A. (1991), Property Investment Depreciation and Obsolescence, Routledge, London.

Baum, A. (1997), Trophy or Tombstone? A Decade of Depreciation in the Central London Office Market. Lambert Smith Hampton and HRES: London.

Baum, A and Crosby, N. (2007), Property Investment Appraisal (3e). Blackwell: Oxford.

Baum, A. and Devaney, S. (2008), "Depreciation, Income Distribution and the UK REIT", Journal of Property Investment and Finance, Vol 26 No. 3 pp. 195-209.

Baum, A. and Turner, N. (2004), "Retention Rates, Reinvestment and Depreciation in European Office Markets", Journal of Property Investment and Finance, Vol 22 No. 3 pp. 214-235.

Brown, G.R. and Matysiak, G.A. (2000), Real Estate Investment: A Capital Market Approach, FT Prentice Hall: Harlow.

Bruhl, M. (2001), "Real Estate Valuations: Standards and Models of Professional Organisation", Conference paper to RICS Europe, Brussels, September.

CBRE (2007), A Guide to the CB Richard Ellis Rent and Yield Monitor, London: CB Richard Ellis.

CEM (1999), The Dynamics and Measurement of Commercial Property Depreciation in the UK, College of Estate Management: Reading.

Crosby, N. and Murdoch, S. (2001) "Basis of rental value for performance measurement systems". Journal of Property Research Vol 18 No. 2 pp. 123-40.

Crosby, N., Lizieri, C. and McAllister, P. "Means, Motive and Opportunity? Disentangling Client Influence on Performance Measurement Appraisals", Journal of Property Research, Vol 27 No. 2 pp. 181-201.

Diaz, J. (1999). "The First Decade of Behavioral Research". Journal of Property Valuation and Investment, Vol 17 No. 4 pp. 326-32.

Diaz, J. (2002). Behavioral Research in Appraisal and Some Perceptions on Implications for Practice. RICS: London

Downie, M. L., Schulte, K. W. and Thomas, M. (1996), "Germany" in Adair, A., Downie, M. L., McGreal, S. and Vos, G. (Eds), European Valuation Practice, E \& FN Spon: London.

Dunse, N. and Jones, C. (2005), "Rental Depreciation, Obsolescence and Location: the Case of Industrial Properties", Journal of Property Research, Vol 22 No. 2-3 pp. 205-223.

Geltner, D., MacGregor, B. and Schwann, G. (2003), "Appraisal Smoothing and Price Discovery in Real Estate Markets", Urban Studies, Vol 40 No. 5-6 pp. 1047-64.

This article is (C) Emerald Group Publishing and permission has been granted for this version to appear here (http://centaur.reading.ac.uk/). Emerald does not grant permission for this article to be further copied / distributed or hosted elsewhere without the express permission from Emerald Group Publishing Limited. 
Hoesli, M. and MacGregor, B. D. (2000), Property Investment Principles and Practice of Portfolio Management, Longman: Harlow.

Hotelling, H. (1925), "A General Mathematical Theory of Depreciation", Journal of American Statistical Association, Vol 20 pp 340-53.

Hulton C.R. and Wykof, F.C. (1976), "The Economic Depreciation of Non-Residential Structures", Working Paper in Economics No 16, John Hopkins University, Baltimore.

Hulton C.R. and Wykof, F.C. (1981a), "The Estimation of Economic Depreciation Using Vintage Asset Prices: An Application of the Box-Cox Power Transformation", Journal of Econometrics, Vol 15 pp 367-396

Hulton C.R. and Wykof, F.C. (1981b), "The Measurement of Economic Depreciation" in Hulten, C.R. (ed), Depreciation, Inflation and the Taxation of Income from Capital, Urban Institute Press: Washington DC.

Hulton C.R. and Wykof, F.C. (1996), "Issues in the measurement of economic depreciation", Economic Enquiry, Vol 34 pp. 10-23.

IPD (2008), The IPD Index Guide, Edition Four - September 2008, Investment Property Databank: London

IPD (2009), IPD Global Property Index, Investment Property Databank: London.

IPD GmbH (2007), Erläuterungen zum Datenerhebungsblatt (Version 12.0), Investment Property Databank (Gmbh): Wiesbaden.

IPF (2005), Depreciation in Commercial Property Markets, Investment Property Forum / IPF Educational Trust, London.

IPF (2009), Current Issues in Property Investment Valuation, Investment Property Forum: London.

IPF (2010), Depreciation of Office Investment Property in Europe, Investment Property Forum I IPF Educational Trust, London.

JLL (2010), Global Real Estate Transparency Index 2010, Jones Lang LaSalle, London.

JLW (1987), Obsolescence: The Financial Impact of Property Performance, Jones Lang Wootton: London.

Jorgenson. D.W. (1996), "Empirical Studies of Depreciation”, Economic Enquiry, Vol 34: pp. 24-42.

Law, V. (2004), "The Definition and Measurement of Rental Depreciation in Investment Property", Unpublished PhD dissertation, University of Reading: Reading

McParland, C., Adair, A., McGreal, S. (2002), "Valuation standards: a comparison of four European countries", Journal of Property Investment and Finance, Vol 20 No. 2 pp. 12741.

Salway, F. (1986), Depreciation of Commercial Property, Calus Research Report, College of Estate Management: Reading.

Taubman, P.and Rasche, R.H. (1969), "Economic and Tax Depreciation of Office Buildings". National Tax Journal, Vol 22 pp 334-46.

This article is (c) Emerald Group Publishing and permission has been granted for this version to appear here (http://centaur.reading.ac.uk/). Emerald does not grant permission for this article to be further copied / distributed or hosted elsewhere without the express permission from Emerald Group Publishing Limited. 
Turner, N. (2001), "Property is not Microsoft", Paper presented at the IPD/GPR European Strategies Conference, Wiesbaden: May.

Wolverton, M.L. (1998) "Empirical analysis of the breakdown method of estimating physical depreciation". The Appraisal Journal, April, pp. 163-171.

This article is (c) Emerald Group Publishing and permission has been granted for this version to appear here (http://centaur.reading.ac.uk/). Emerald does not grant permission for this article to be further copied / distributed or hosted elsewhere without the express permission from Emerald Group Publishing Limited. 
Table 1: Sample Sizes and Time Horizons for European Office Markets Data

\begin{tabular}{lccc}
\hline & Time horizon & $\begin{array}{c}\text { Number of } \\
\text { properties }\end{array}$ & $\begin{array}{c}\text { \% of all IPD at } \\
\text { start of period }\end{array}$ \\
\hline Amsterdam & $10 \mathrm{yr}$ & 38 & $36 \%$ \\
Dublin & $10 \mathrm{yr}$ & 35 & $36 \%$ \\
Frankfurt & $10 \mathrm{yr}$ & 17 & $22 \%$ \\
London: City & $10 \mathrm{yr}$ & 80 & $16 \%$ \\
London: West End & $10 \mathrm{yr}$ & 135 & $19 \%$ \\
Paris & $8 \mathrm{yr}$ & 168 & $18 \%$ \\
Stockholm & $10 \mathrm{yr}$ & 36 & $16 \%{ }^{2}$ \\
\hline
\end{tabular}

Note 1 : i.e. end-1997 in the case of all cities apart from Paris, where this is end-1999. The percentage is in terms of the number of all assets in that city within the IPD databank at that point.

Note 2 : The All IPD figures refer to properties in Stockholm CBD and Central area, and exclude Rest of Greater Stockholm where there is no sample representation

Table 2: Rent Points for European Office Markets

\begin{tabular}{lccc}
\hline & Time horizon & $\begin{array}{c}\text { No. of rent } \\
\text { points spanning } \\
\text { period }\end{array}$ & $\begin{array}{c}\text { No. of rent } \\
\text { points used }\end{array}$ \\
\hline Amsterdam & $10 \mathrm{yr}$ & 9 & 6 \\
Dublin & $10 \mathrm{yr}$ & 6 & 3 \\
Frankfurt & $10 \mathrm{yr}$ & 19 & 10 \\
London: City & $10 \mathrm{yr}$ & 19 & 16 \\
London: West End & $10 \mathrm{yr}$ & 18 & 15 \\
Paris & $8 \mathrm{yr}$ & 57 & 35 \\
Stockholm & $10 \mathrm{yr}$ & 2 & 1 \\
\hline
\end{tabular}

This article is (c) Emerald Group Publishing and permission has been granted for this version to appear here (http://centaur.reading.ac.uk/). Emerald does not grant permission for this article to be further copied / distributed or hosted elsewhere without the express permission from Emerald Group Publishing Limited. 
Table 3: Annualised rental depreciation and rental growth rates

\begin{tabular}{lccccc}
\hline & $\begin{array}{c}\text { Number of } \\
\text { properties }\end{array}$ & $\begin{array}{c}\text { Rate of rental } \\
\text { depreciation }\end{array}$ & $\begin{array}{c}\text { Rental growth of } \\
\text { benchmarks }\end{array}$ & $\begin{array}{c}\text { Rental growth of } \\
\text { the sample }\end{array}$ & $\begin{array}{c}\text { Total } \\
\text { expenditure } \\
\text { rate }^{3}\end{array}$ \\
\hline Amsterdam & 38 & $-0.4 \%$ & $3.2 \%$ & $3.6 \%$ & $0.8 \%$ \\
Dublin & 35 & $1.7 \%$ & $9.5 \%$ & $7.7 \%$ & $0.3 \%$ \\
Frankfurt & 17 & $4.9 \%$ & $2.9 \%$ & $-2.1 \%$ & $0.6 \%$ \\
London: City & 80 & $0.4 \%$ & $2.3 \%$ & $1.9 \%$ & $0.7 \%$ \\
London: West End & 135 & $2.2 \%$ & $9.0 \%$ & $6.6 \%$ & $0.7 \%$ \\
Paris & 168 & $-1.1 \%$ & $4.3 \%$ & $5.4 \%$ & $0.7 \%$ \\
Stockholm & 36 & $-2.0 \%$ & $3.9 \%$ & $5.9 \%$ & $1.3 \%$ \\
\hline
\end{tabular}

1. Negative results indicate where appreciation of the sample has taken place relative to the benchmark

2. Benchmark growth rates here and throughout the chapter reflect the particular mix of rent points used rather than any published rental series. This mix is designed to match the locations of the sample assets.

3. Total expenditure is calculated from the sum of capital and maintenance expenditure by owners as recorded in IPD sample data.

Table 4: Correlations between sample and benchmark year-by-year rental growth

\begin{tabular}{|c|c|c|c|c|}
\hline & $\begin{array}{c}\text { Column } 1 \\
\text { Sample size of } \\
\text { young cohort }\end{array}$ & $\begin{array}{c}\text { Column } 2 \\
\text { Young cohort } \\
\text { vs. benchmarks }\end{array}$ & $\begin{array}{c}\text { Column } 3 \\
\text { Whole cohort } \\
\text { vs. } \\
\text { benchmarks }\end{array}$ & $\begin{array}{l}\text { Column } 4 \\
\text { Young cohort } \\
\text { vs. whole } \\
\text { cohort }\end{array}$ \\
\hline Amsterdam & 9 & 0.62 & 0.64 & 0.87 \\
\hline Dublin & 7 & 0.75 & 0.82 & 0.95 \\
\hline Frankfurt & 6 & $0.03^{* *}$ & $0.08^{\star \star}$ & $0.54^{*}$ \\
\hline London: City & 13 & 0.86 & 0.84 & 0.93 \\
\hline London: West End & 20 & 0.95 & 0.97 & 0.96 \\
\hline
\end{tabular}

* indicates that correlation coefficient is significantly different from 1 at the $10 \%$ level and ** at the $5 \%$ level.

This article is (C Emerald Group Publishing and permission has been granted for this version to appear here (http://centaur.reading.ac.uk/). Emerald does not grant permission for this article to be further copied / distributed or hosted elsewhere without the express permission from Emerald Group Publishing Limited. 


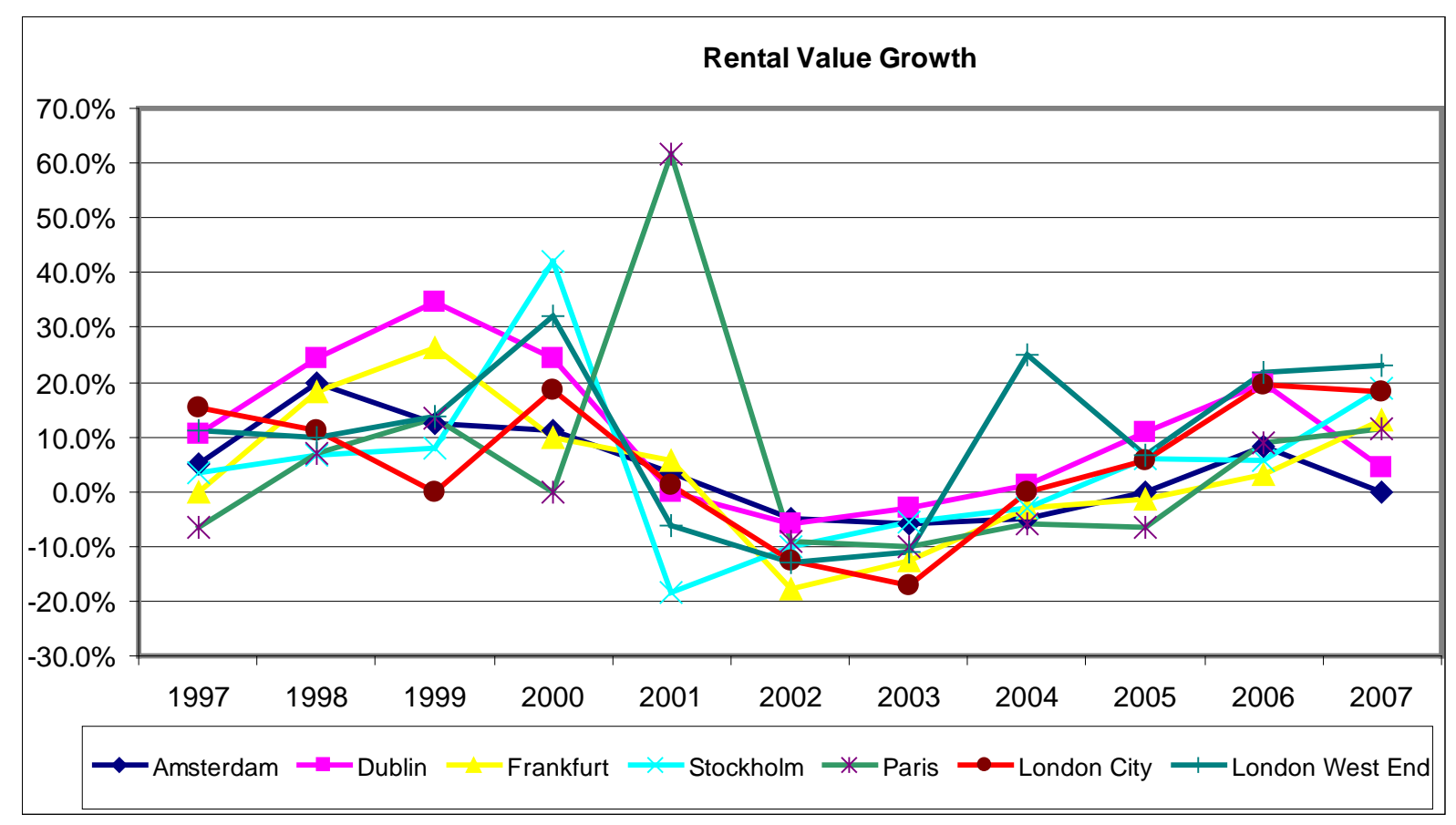

Fig 1 : Office Rental Value Change (\% p.a.) for Seven European Locations - Source CBRE

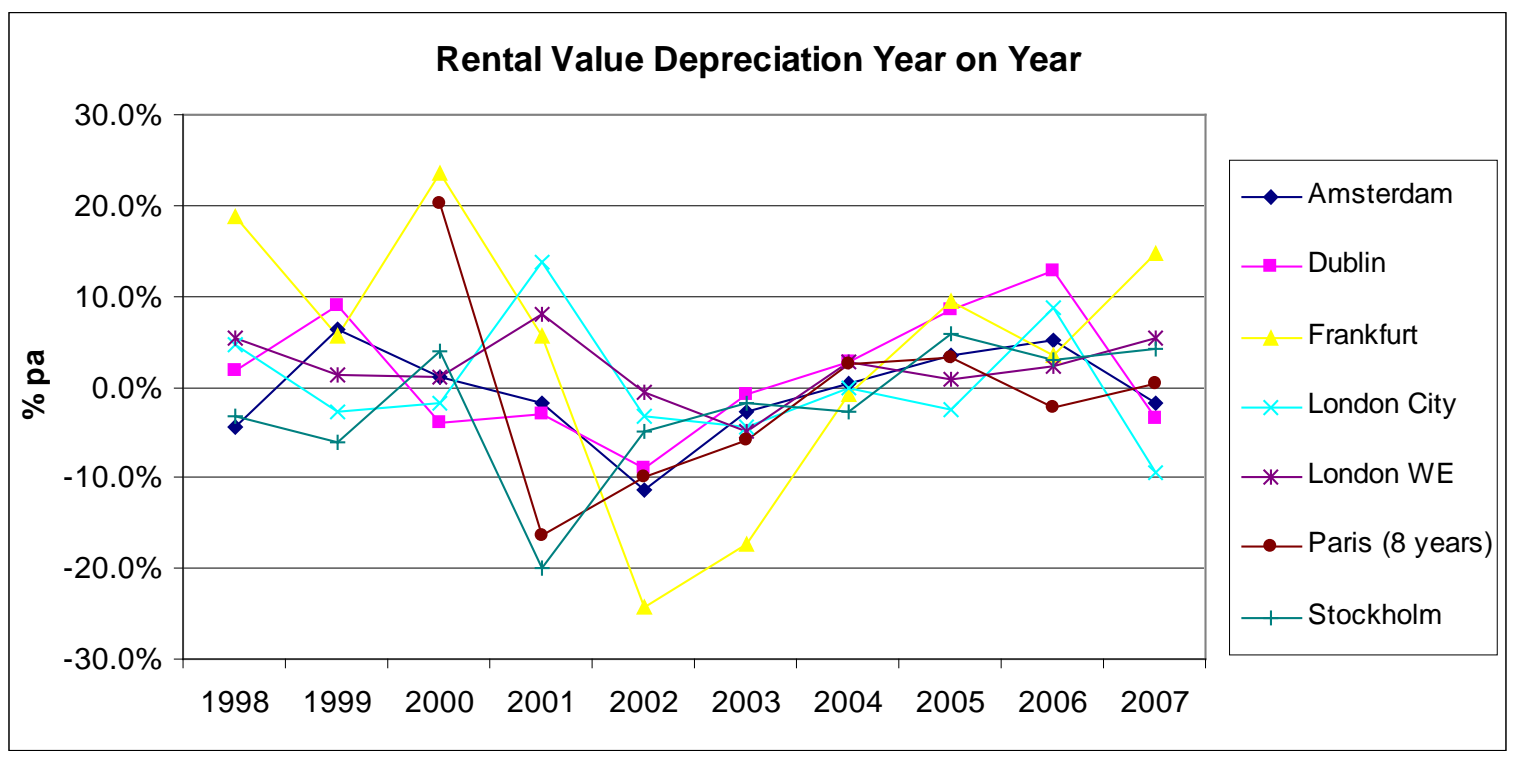

Fig 2 : Annual Rental Value Depreciation Rates 1997 - 2007

This article is (c) Emerald Group Publishing and permission has been granted for this version to appear here (http://centaur.reading.ac.uk/). Emerald does not grant permission for this article to be further copied / distributed or hosted elsewhere without the express permission from Emerald Group Publishing Limited. 


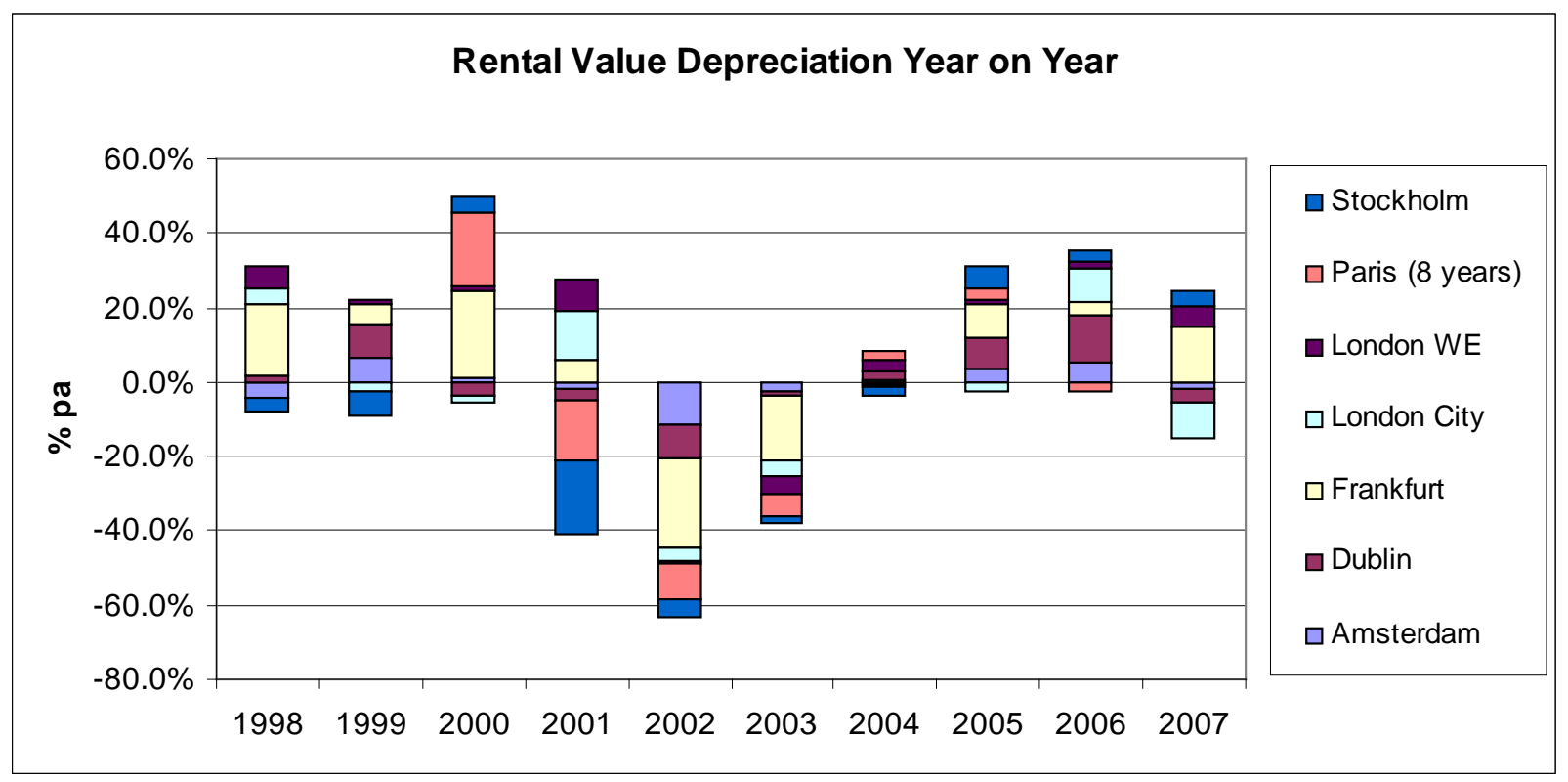

Fig 3.: Sum of Annual Rental Value Depreciation Rates 1997 - 2007

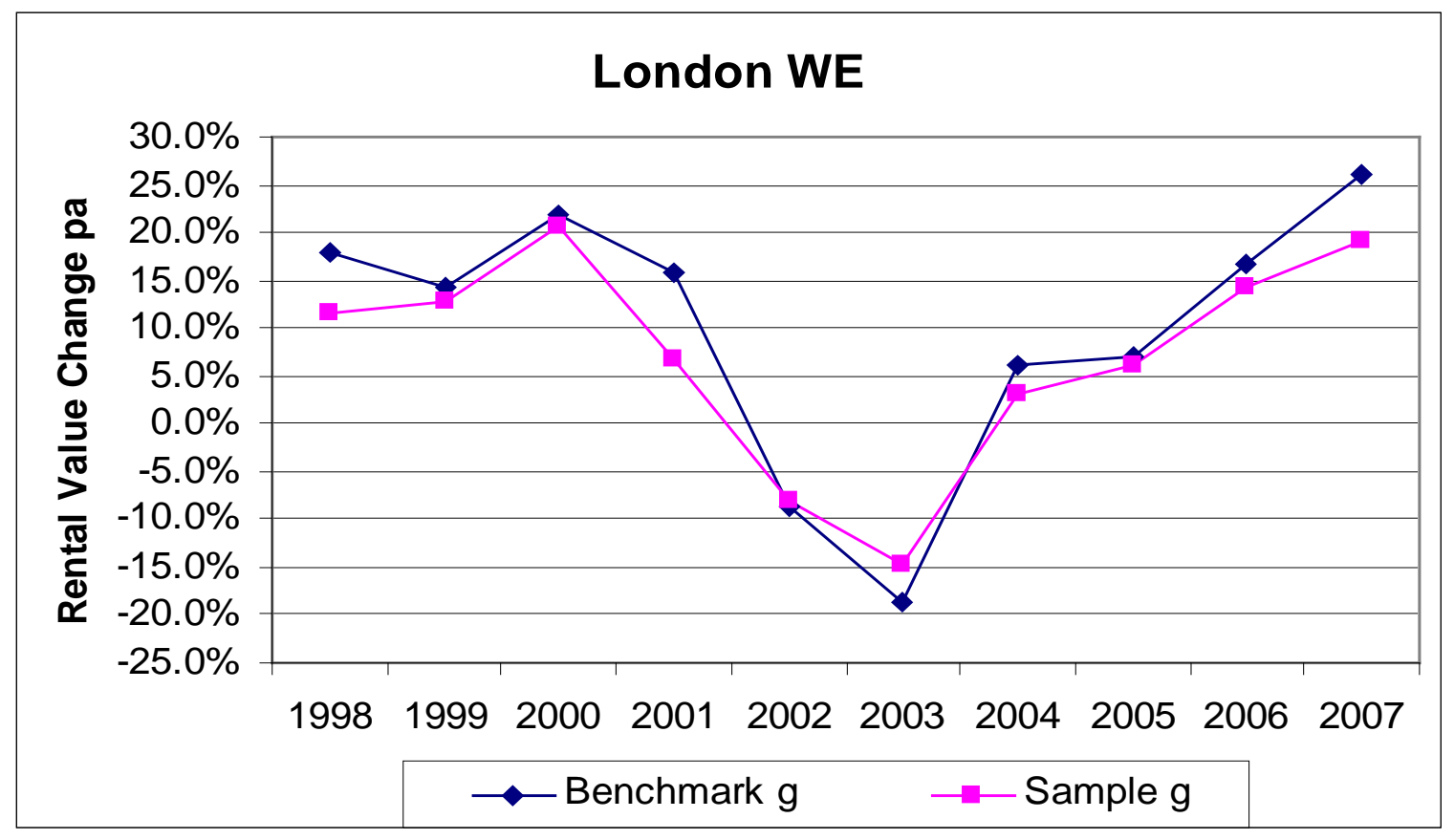

Fig 4 : Comparison of the annual change in benchmark and sample - London WE

This article is (c) Emerald Group Publishing and permission has been granted for this version to appear here (http://centaur.reading.ac.uk/). Emerald does not grant permission for this article to be further copied / distributed or hosted elsewhere without the express permission from Emerald Group Publishing Limited. 


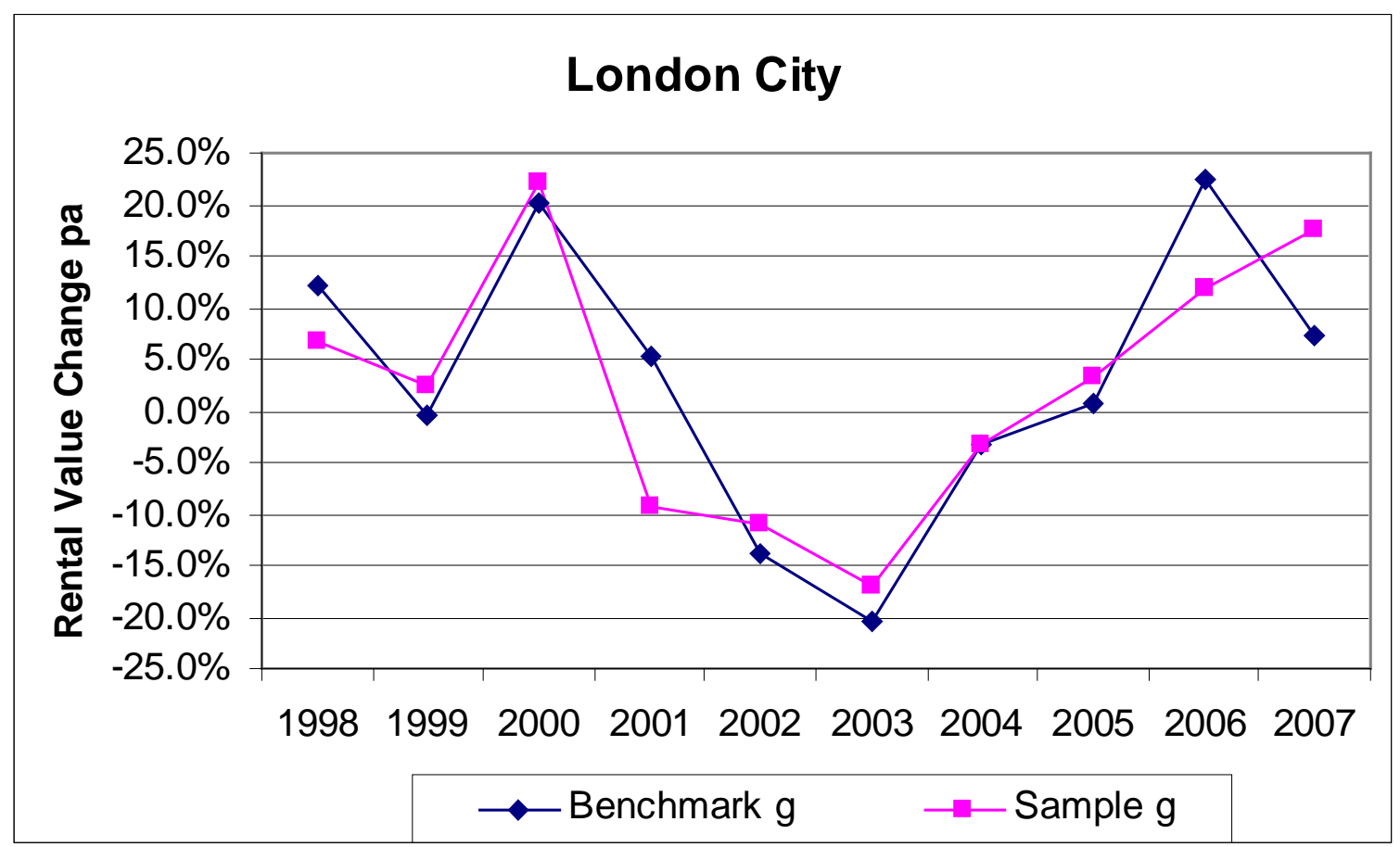

Fig 5. : Comparison of the annual change in benchmark and sample - London City

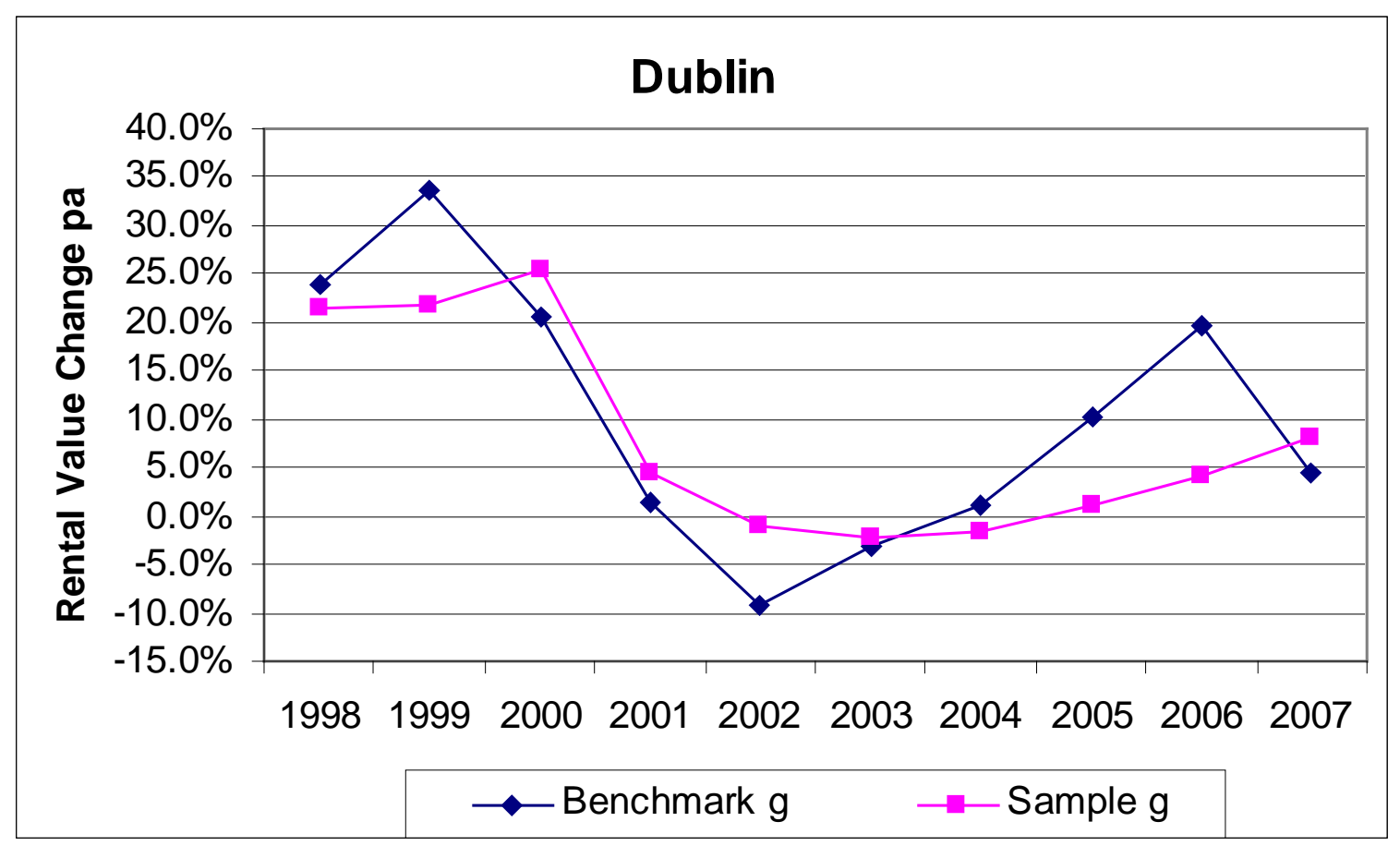

Fig 6 : Comparison of the annual change in benchmark and sample - Dublin

This article is (c) Emerald Group Publishing and permission has been granted for this version to appear here (http://centaur.reading.ac.uk/). Emerald does not grant permission for this article to be further copied / distributed or hosted elsewhere without the express permission from Emerald Group Publishing Limited. 


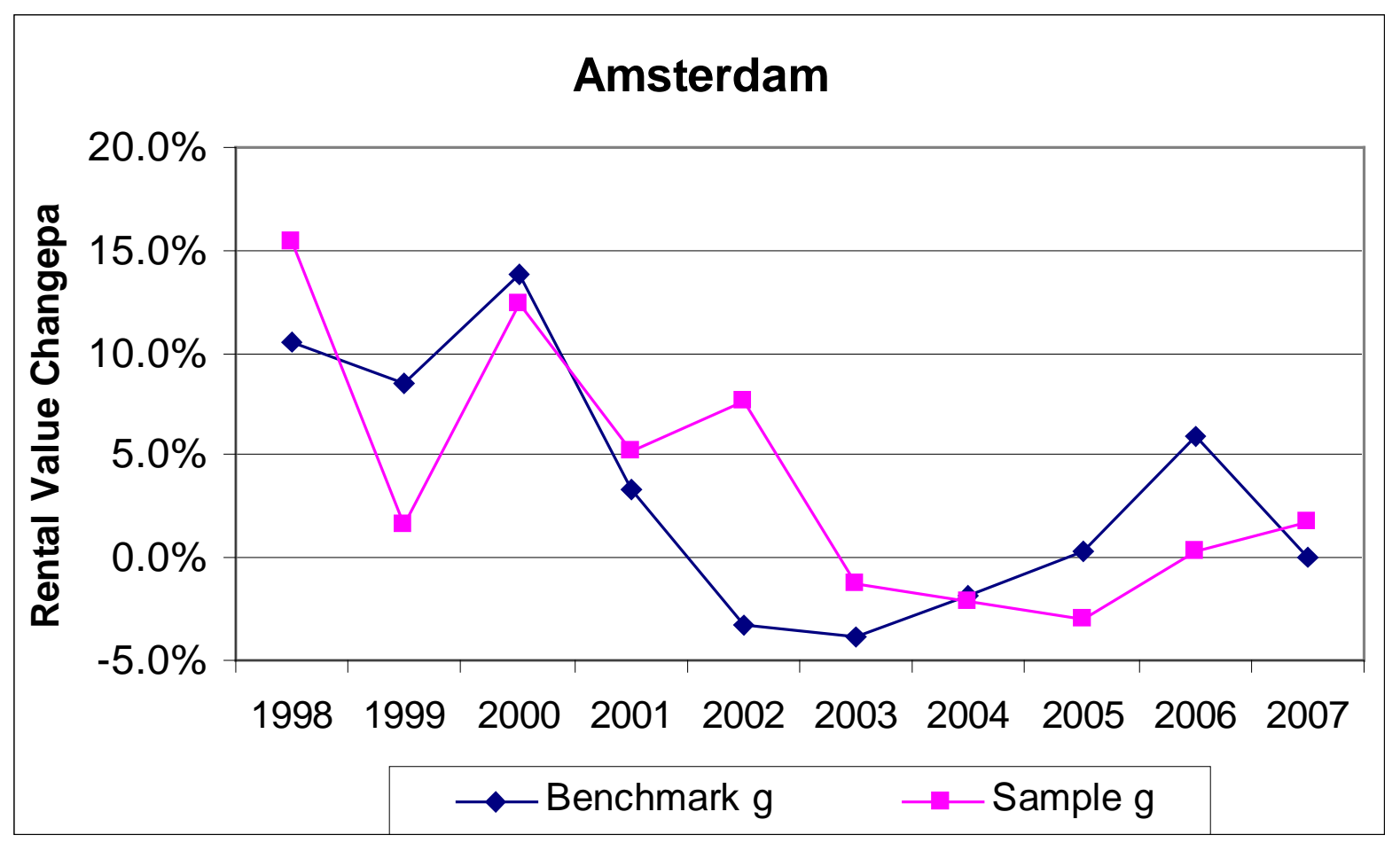

Fig 7 : Comparison of the annual change in benchmark and sample - Amsterdam

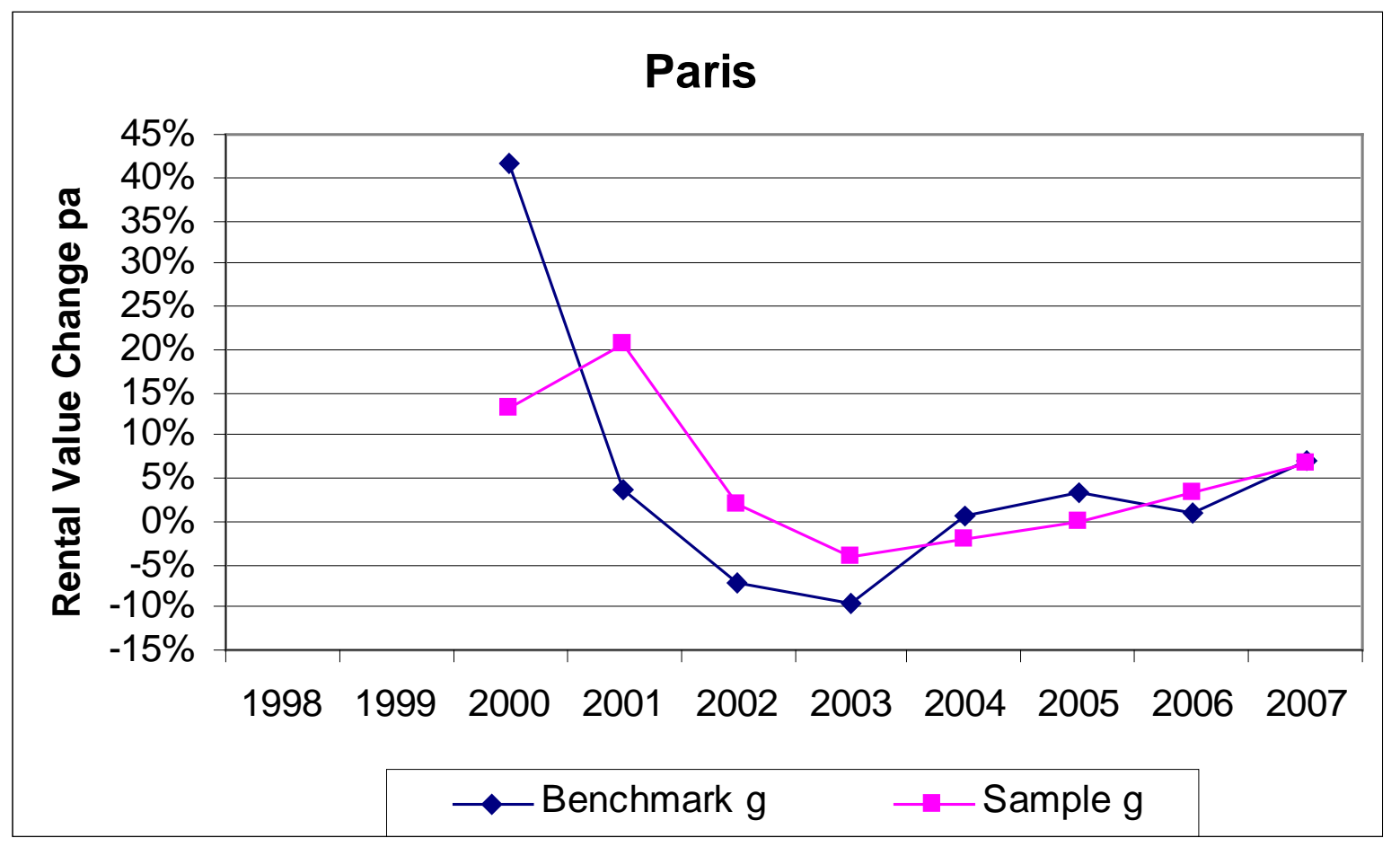

Fig 8 : Comparison of the annual change in benchmark and sample - Paris

This article is @ Emerald Group Publishing and permission has been granted for this version to appear here (http://centaur.reading.ac.uk/). Emerald does not grant permission for this article to be further copied / distributed or hosted elsewhere without the express permission from Emerald Group Publishing Limited. 


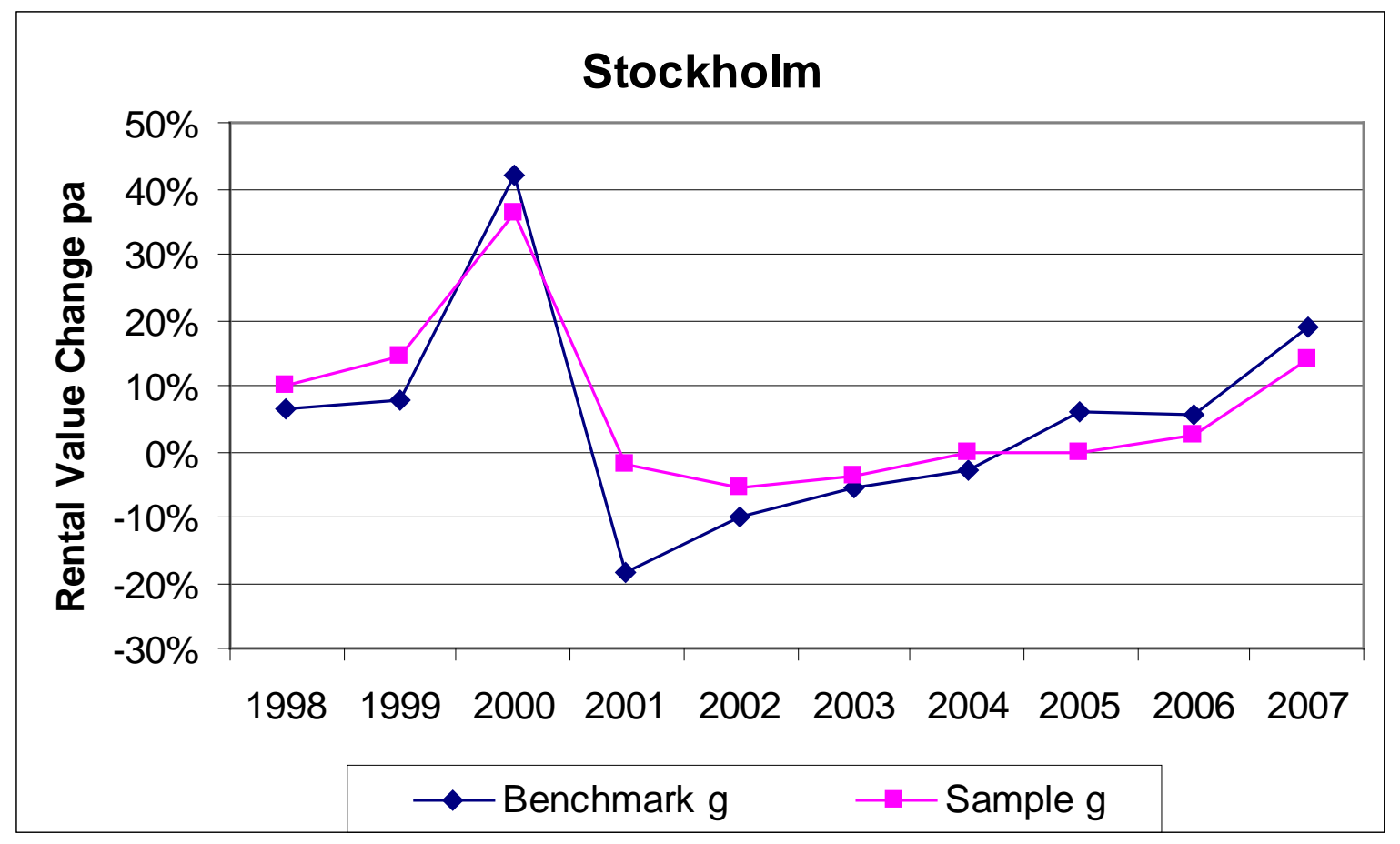

Fig 9 : Comparison of the annual change in benchmark and sample - Stockholm

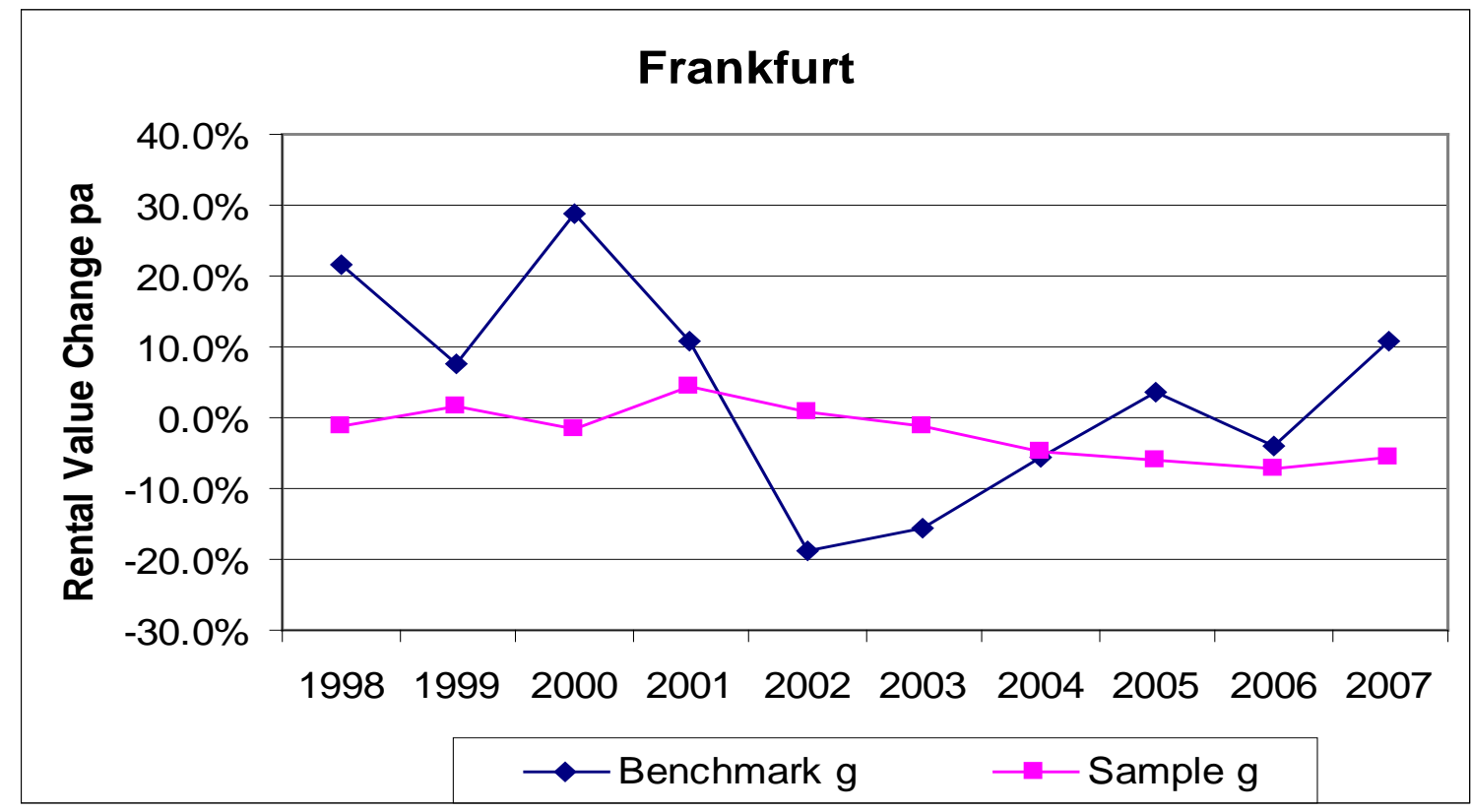

Fig 10 : Comparison of the annual change in benchmark and sample - Frankfurt

This article is (c) Emerald Group Publishing and permission has been granted for this version to appear here (http://centaur.reading.ac.uk/). Emerald does not grant permission for this article to be further copied / distributed or hosted elsewhere without the express permission from Emerald Group Publishing Limited. 